\title{
Monocytes to Total Cell Ratio Measurement
}

National Cancer Institute

\section{Source}

National Cancer Institute. Monocytes to Total Cell Ratio Measurement. NCI Thesaurus.

Code C98872.

The determination of the ratio of monocytes compared to total cells present in a sample. The measurement may be expressed as a ratio or percentage. 